\title{
Role of thermal spray in combating climate change
}

\author{
V. Viswanathan ${ }^{1} \cdot$ Nirmal Kumar Katiyar $^{1} \cdot$ Gaurav Goel $^{2} \cdot$ Allan Matthews $^{3} \cdot$ Saurav Goel ${ }^{1,4,5,6,7,8}$
}

Received: 3 July 2021 / Accepted: 25 September 2021 / Published online: 26 October 2021

(c) The Author(s) 2021

\begin{abstract}
Thermal spraying is a scalable surface engineering technique used to add or to restore functionality of a solid surface by applying a coating. Examples of this include protection against wear, erosion, abrasion, and heat. In a specific sense, thermal spraying is particularly used to deposit thermal barrier coatings (TBCs) which finds use in transportation, power generation and automotive sector. As being a surface technique, thermal spraying much like other surface coating techniques can avoid the use of excessive bulk materials and in turn offers longevity to the life of the component, so it already contributes to the reduction of global warming by virtue of avoiding the use of excessive scarce materials and improving fuel efficiency. In terms of its contribution to the cause of global warming, thermal spraying stands in sharp contrast to the energy-intensive processes such as melting, casting, extrusion and welding. With the rise of additive manufacturing, it is possible to use thermal spray to complement that process in many ways and "cold spray additive manufacturing" (CSAM) is already gaining popularity. The thermal spraying technique relies on using selective types of gases-hydrogen being one of them and few types of metals/alloys which are now classed as critical raw materials due to them being on the supply risk register. Efforts to consider recycling and reuse and to find alternatives to these are very timely to continue drawing the advantage of thermal spraying being a relatively green technique. In particular, the green energy initiatives and the drive to develop energy storage and battery technologies could challenge the supply of raw materials such as hydrogen gas and rare earth elements. This underlines the research and development need for alternate materials and processes to address the issue of climate change which is the major focal point of the COP 26 Summit at Glasgow in 2021. The combination of digital technologies and thermal spray coatings will reduce gas, powder and power consumption, which will make this manufacturing process even greener.
\end{abstract}

Keywords Critical raw materials $\cdot$ Thermal spray $\cdot$ Climate change $\cdot$ Materials science and engineering $\cdot$ Energy conservation

Saurav Goel

GOELS@LSBU.AC.UK

1 London South Bank University, 103 Borough Road, London SE1 0AA, UK

2 Thapar Institute of Engineering Technology, Patiala 147004, India

3 The University of Manchester, Manchester M13 9PL, UK

4 Cranfield University, Cranfield MK430AL, UK

5 Shiv Nadar University, Gautam Budh Nagar 201314, India

6 Indian Institute of Technology Guwahati, Guwahati 781039, India

7 University of Petroleum and Energy Studies, Dehradun 248007, India

8 Harbin Institute of Technology, Harbin, Heilongjiang 150001, People's Republic of China

\section{Introduction}

Addressing the concerns raised in the G7 summits and many other forums about climate change, the UK, as the host to the UN's COP26 summit in Glasgow in November 2021, has been encouraged by this COP26 initiative and the academic and industrial communities have worked towards net-zero manufacturing, and efforts are underway to embrace digital technologies to develop better recycling processes. Thermal spraying is a coating process used to manufacture surfaces for various harsh industrial applications. About $50 \%$ of the thermal spray coatings are used in aerospace and power generation which already speaks for the harshness of the environments [1,2]. The use of thermal spray is critical for various applications, which can affect the mining of critical raw materials (CRMs) such as Ti, Y, Ni, Co, and W. As such, thermal spraying

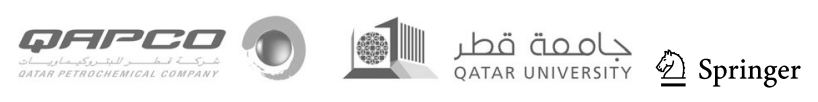


by itself has been contributing to less mining by way of reducing, reusing, and recycling of the base materials that are coated [3,4]. Thermal spraying avoids discarding of expensive superalloys by allowing selective repair of gas turbine or aero engine components, which would otherwise contribute to more greenhouse gas ( $\mathrm{GhG})$ emissions in the form of remelting, casting and further downstream processes such as machining. Moreover, thermal spray requires less energy for surface treatment (such as electrical energy, thermal energy, or kinetic energy) compared to other processes such as casting, welding metal forming and laser hole drilling. The US Energy Information Administration [5] estimated the energy consumption by the primary metal industries in 2018 to be about 2041 trillion BTU (600 billion $\mathrm{kWh}$ ). Surface engineering (coatings and treatments) offers a means to reduce the energy consumed by such primary industries. If not for surface engineering, it would need more mining and consumption of raw materials to cater to the ever-increasing demand for metals such as iron, steel, nickel, and cobalt. Besides the traditional industries, the thermal spraying will be an indispensable part of the renewable energy industry where many diverse parts such as wind towers and solar PV cells are frequently coated.

This article presents key insights on various aspects of thermal spray processes especially paying attention to the role of critical raw materials, the gases used, the amount of electrical energy consumed, and how we can reduce the carbon footprint of this process itself while contributing to the reuse efforts for the base materials.

\section{Thermal spray market}

Thermal spraying is estimated to be a USD 10 billion market worldwide and it is poised to grow to about USD 25.82 billion by 2027 [6, 7]. A cursory look at the market reveals that plasma spray and flame spray together contributes to $50-60 \%$ to this market. As it may be noted, these two processes use either electric power or hydrocarbons to deposit coatings. Hence, there is a significant opportunity to reduce the carbon footprint in this sector. Figure 1 reveals the US share of each subset of the thermal spray process. In this illustration, the cold spray technique has also been included since they all cater to the same customer base [8].

The aviation and power generation industries hold a USD 5-6 billion market share of the thermal spray market which represent $50-60 \%$ of the market. Thermal spray applies overlay coatings on items like castings and fabricated parts such as metal flanges and mating parts, and paper and food processing rolls. As a refurbishment industry, this sector will enable industries not to discard base materials after a certain time interval and continue to use them for the next life cycle after reapplication of the coating.

Thermal spray is projected to dip in market value (Fig. 2) due to the pandemic but is well positioned to rise in the market due to the continuous rise in the demand for energy applications which need components such as turbine blades (wind and gas) as well as oil drilling to be coated by thermal spray. A bar chart (Fig. 3) shows the importance of thermal spray for a wide variety of sectors. Sectors such as agricultural machinery, healthcare, electronics, and paper industries
Fig. 1 US share of different thermal spray processes. Plasma and combustion spray are among the popular choices (data has been used from [9])

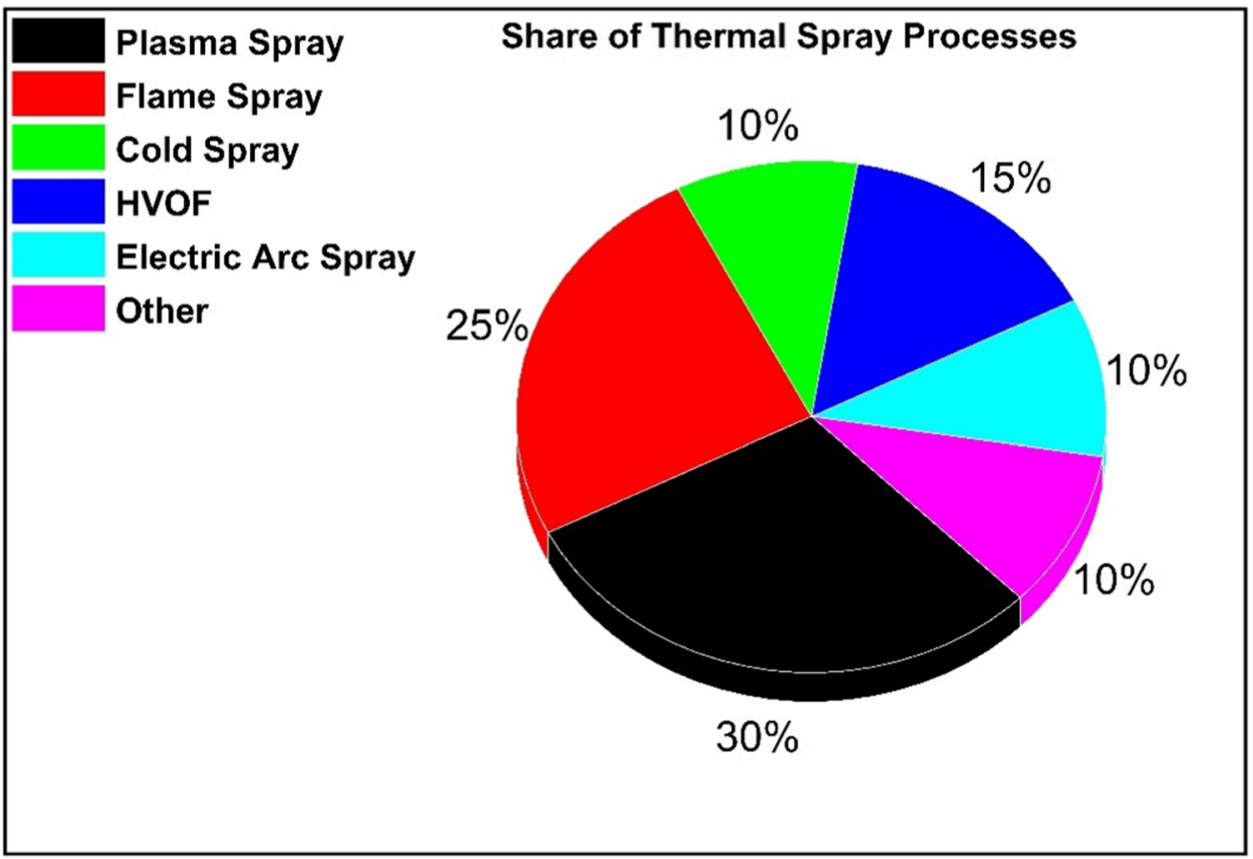



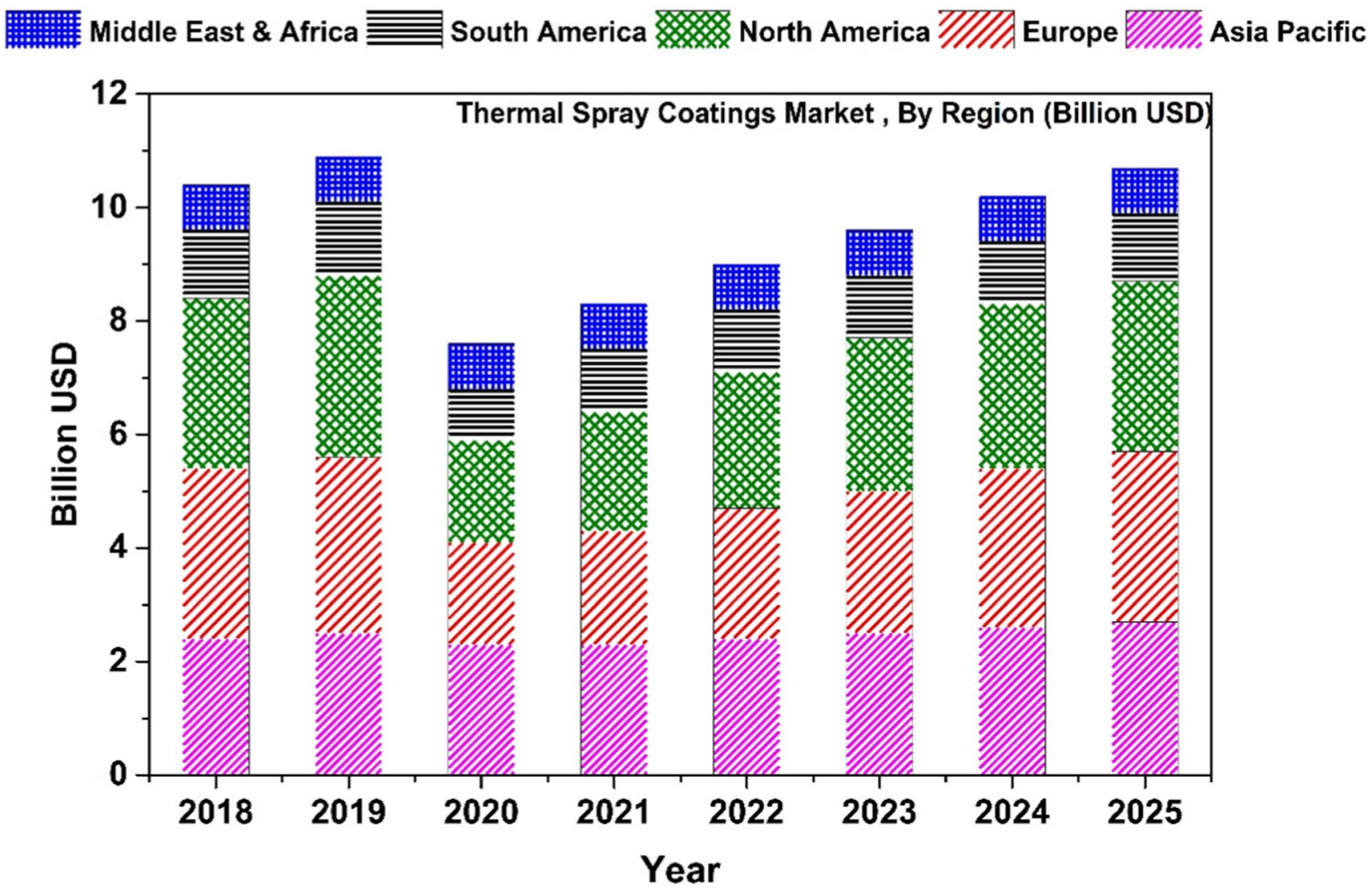

Fig. 2 Prevalent and near future market share of thermal spray in various continents (based on the data used from [6])

Fig. 3 US thermal spray market showing the dominance of the industry by power and aviation sectors (data reproduced from [10])

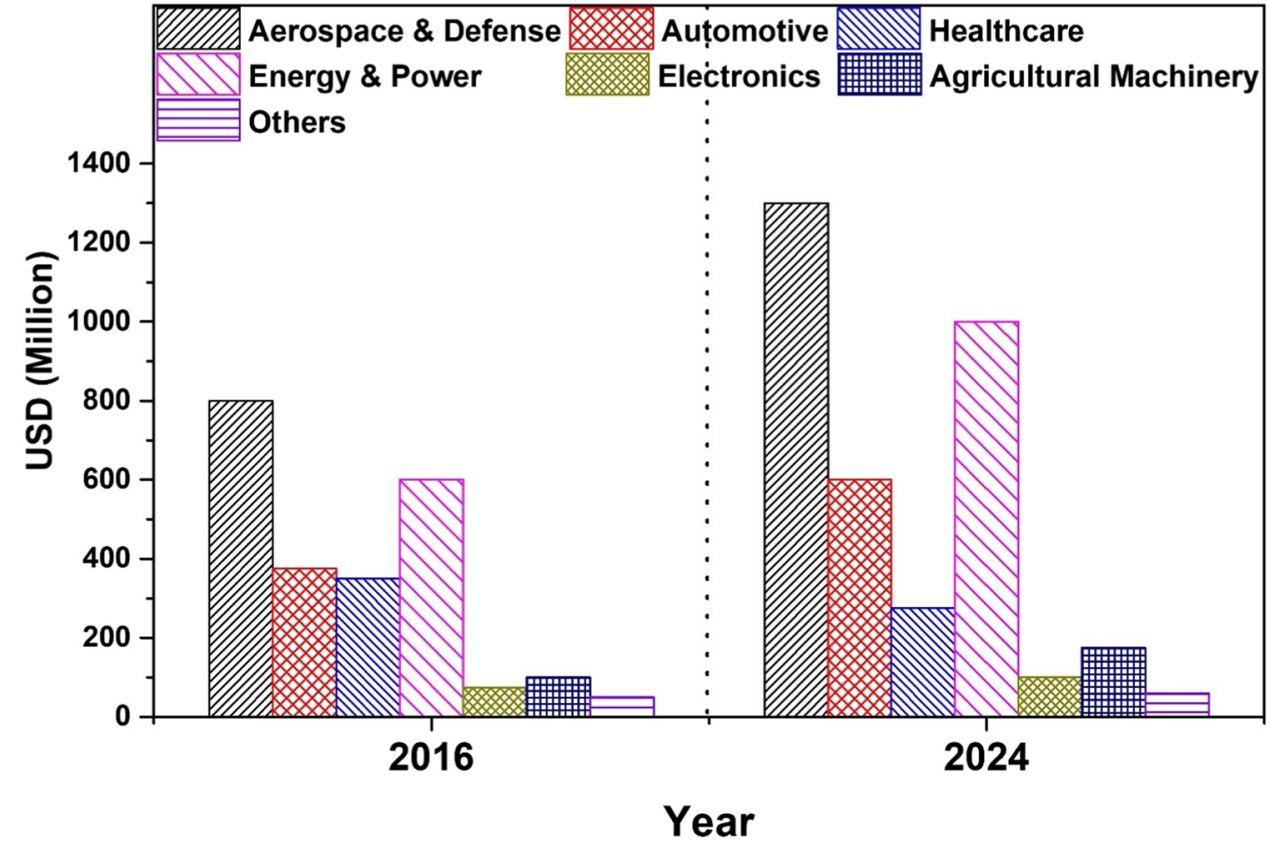

also make use of thermal spraying technology but the growth in these sectors by 2024 compared to 2016 is not as significant as it will be in the aviation and power sectors.
The labour cost would continue to dictate the raw material usage and its transportation. In spite of the high labor costs, the USA continues to produce thermal spray coatings 
at a much higher rate than other countries. However, the scarcity of raw materials and the sustained pressure on governments to cut GhGs could shift the thermal spray manufacture markets to official development assistance (ODA) countries, although the processing of raw materials to thermal spray would remain with selective countries due to the importance of proprietary information. Nitrogen and hydrogen would find more prominent use in producing thermal spray coatings compared to hydrocarbons in the western world, while the developing nations might continue to burn fossil fuels. To have a sustainable eco balance, it is important to provide better access to environmentally clean gases to the developing nations. Export controlled technologies such as vacuum plasma spray and electron-beam physical vapor deposition (EBPVD) utilize high energy and could be replaced with overlay coatings for turbine blades such as HVOF and plasma spray in the next decade or so.

\section{Power, gas, and raw materials-key to combating climate change}

Seventy-seven percent of the energy that industries currently consume is through manufacturing and $12 \%$ of the energy [11] is consumed by mining industries. Within manufacturing alone, metal industry carries about 10-15\% energy for various processes such as casting, forming, welding, and brazing. Coating and thermal spray specifically is just a small fraction of this percentage.

Let us understand the key contributing elements to climate change in thermal spray through a schematic in Fig. 4. Estimates show that about 2 million $\mathrm{kg}$ of YSZ [12] was used for coatings in 2015 alone. If the coating deposition efficiency was $60 \%$, then about 800 tons of powder was wasted during spray. Eight weight percent of $\mathrm{Y}_{2} \mathrm{O}_{3}$ in the powder means 64 tons of yttrium oxide (50 tons of yttrium after subtracting the weight of oxygen) was wasted in 2015 alone. Yttrium being a precious critical raw material cannot afford to be wasted. Hence, there is a pressing need to recycle the waste powder using chemical or mechanical methods. Masks and polymeric compounds used are an environmental hazard and we need to find ways to reduce or recycle the masking materials. Hydrocarbons are mostly from the combustion processes and hence it is pertinent to switch to clean fuel like hydrogen. Hence, the input and output of thermal spray have to be managed well to have a positive impact on the environment (Fig. 4).

Each plasma spray process installation uses energy from $20 \mathrm{~kW}$ to up to $200 \mathrm{~kW}$. This high energy requirement comes from the need to melt and splat the molten droplet of ceramics, cermets, and metals. High energy is also important to increase the throughput of the particles thereby increasing the deposition efficiency.

Gun power is decided by the melting point of metals, alloys, cermets and ceramics that are to be deposited. $50 \mathrm{~kW}$ to $100 \mathrm{~kW}$ is the mostly used power requirement for most of the thermal spray industries. If we have 5000 of these plasma spray guns operating in the world over all 365 days, this corresponds to $500 \mathrm{MWh}$ of energy consumed annually.

Figure 5 gives an overview of the gun power of some important OEM plasma spray guns. The selection of gun for the spray depends on the requirement of a specific type of coating microstructure and mechanical properties.

As such, thermal spray uses a limited number of gases to deposit coatings at a commercial scale such as hydrogen, oxygen, propane, acetylene, nitrogen, argon, helium, and propylene. Barring hydrogen, most of the other gases fall in the hydrocarbon category thereby contributing to GhGs. Besides gases, liquid fuels such as kerosene, Jet B fuel is used to combust and melt the coating powders. Figure 6(a) shows a bar chart of heavily used industrial gases while Fig. 6(b) shows that there is a potential to develop parameters and switch to cleaner fuels.

Hydrocarbons are currently popular in the thermal spray industry due to economical and geographical reasons. While big corporations can afford spraying with hydrogen and
Fig. 4 Input raw materials and output waste generated
Input

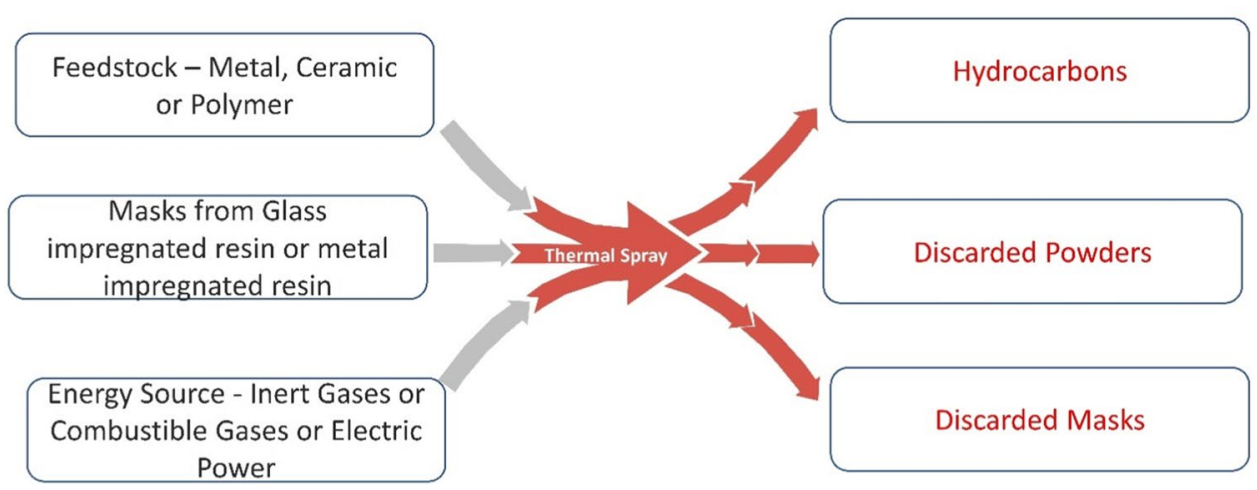

Waste products QATAR UNIVERSITY 
Fig. 5 Power $(\mathrm{kW})$ used to generate porous/dense coatings (Gun names are trademark names of several OEMs.) adapted from manuals from manufacturers
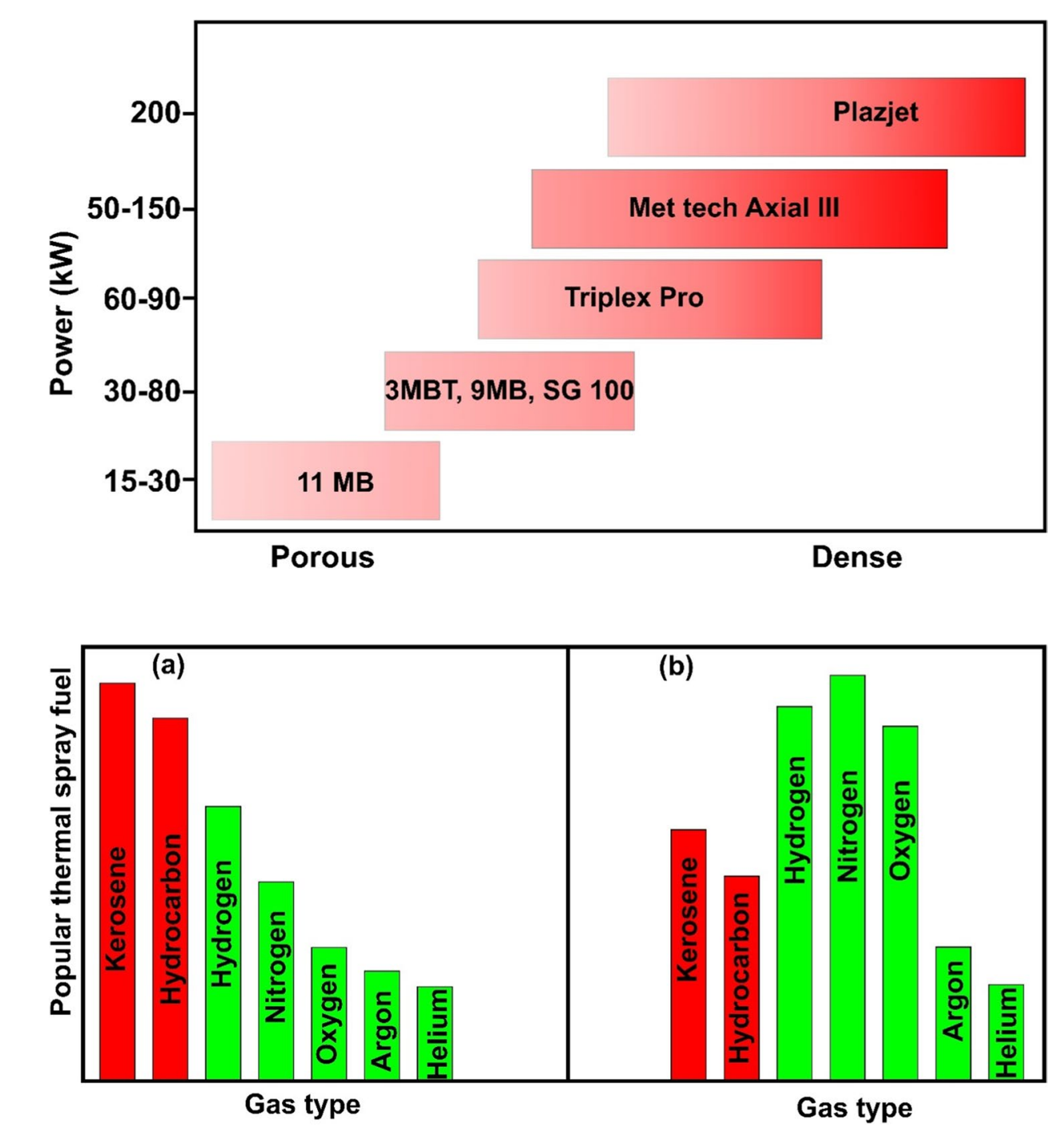

Fig. 6 a Thermal spray fuel consumption presently; (b) a potential to move away from hydrocarbons soon. Data projected from $[6,9,13]$ nitrogen, small-scale coating factories are still relying on fossil fuels to stay competitive in the market. Scaling up of hydrogen generators would help to keep the hydrogen costs low and this will encourage small companies to adapt faster. Suppliers producing coatings with clean fuels can be given carbon credits and incentives by the Governments. While helium is a by-product of natural gas, usage of helium in cold spray process is set to increase due to new innovations.

Materials such as $\mathrm{Ti}, \mathrm{Co}, \mathrm{Y}, \mathrm{W}, \mathrm{Ce}, \mathrm{Gd}$, and $\mathrm{Yb}$ continue to remain pivotal to the aviation sector but are now becoming critical raw materials (CRMs) due to the increasing supply risk [14]. These elements are critical to aviation and power generation and hence alternate materials need to be researched and implemented within the next decade. Efforts to recycle these elements from cast or wrought products should be encouraged.

In a high-tech industry like aviation, the engine parts coated are high-quality castings made of $\mathrm{Ni}$ - and Co-based super alloys and they are too expensive to be scrapped at a premature end of life. Recycling and reusing them is energyintensive and coating would be a far better greener option to refurbish the parts as long as their functional and structural requirements are met. Besides, the usage of elements like $\mathrm{Ni}, \mathrm{Co}$, and $\mathrm{Cr}$ needs to be heavily monitored from an environmental perspective through schemes like Registration, Evaluation, Authorisation and Restriction of Chemicals (REACH) in Europe.

If there is no thermal spray refurbishment, $30-50 \%$ of nickel parts will be discarded in the form of metal and alloys and new parts will need to be produced through energyintensive process such as casting, forging, and welding.

In the future, export of rare earth elements would be restricted by the country of origin. This would give them the edge to develop technologies for space and defense applications. The countries in need of these elements must switch to a viable alternative to stay ahead in the space race. Hence, this decade is going to have watershed moments for finding viable alternative to CRMs. 


\section{Thermal spray-an important player in climate change}

Let us consider a market where thermal spray has a major stake such as the manufacturing and refurbishment of industrial gas turbines. Turbine sections involve complex gas paths where the parts are designed to tap the maximum amount of energy of gas to rotate the turbines. It is imperative that these parts have complex profiles [15] with a lot of cooling holes to keep the material free from issues such as fatigue, creep, oxidation, and corrosion. These parts are manufactured from nickel- and cobalt-based super alloys. There are very few suppliers who have proprietary casting methods such as investment casting, directional solidification, and single crystal alloying to manufacture these parts. It involves melting few tons of these alloys and retaining the melt pool for a long time until the solidification happens with the desired microstructural requirement, and this would need immense energy.

OEMs such as General Electric and Siemens have hundreds of such turbines in the global market sold as a new make. For a newly manufactured unit, sourcing these parts from casting or other alloying techniques would make sense. When they start producing power, these turbines have to be refurbished at the OEM stipulated intervals. They are run with natural gas and liquid fuels and thus are subjected to oxidation and other corrosive environments. The coating has a fixed shelf life and when they come to a service center for refurbishment, the parts cannot be discarded owing to the huge replacement costs involved. Coatings are stripped (based on the NDT inspection) and it is decided to recoat the parts to restore it back in the turbines. Let us consider this simple sum. Each part weighs about $10-20 \mathrm{~kg}$ and let us say the amount of nickel used in each part is $60 \%$ by weight. We are talking about discarding $12 \mathrm{~kg}$ of nickel as opposed to stripping coating with few grams of nickel and replacing with a new coating. This by itself is a silent green initiative because of the market-driven profit equations agreeable to both customer and OEMs.

Apart from this, coating life estimation tools are available to calculate the balance life of coating so that parts do not have to be stripped and can be used for another cycle.

If we track these elements from mines to machines, as shown in the Table 1, general trends are pointing to the fact that about $50-80 \%$ of each element mined are subjected to several processing technologies such as casting, extrusion, welding, and drawing. Now if these parts are not coated, the amount of mining required to manufacture these parts will double or triple which is counterproductive to combating climate change.

On the positive side, if we double the efforts to implement thermal spray to $10-20 \%$, the amount of casting and alloying efforts would be reduced significantly, thereby complying with the reduce (mining), reuse (refurbish), and recycle theme.

As shown in Fig. 7, thermal spray has been an indispensable process for several industries. Epoxy primer coatings have volatile organic compounds (VOC) and still form a considerable portion of aesthetic/corrosion prevention methods for carbon steels in developing countries. It will be easy to make the switch to thermal spray aluminum or thermal spray zinc given the abundance of these elements which are not in the CRM list.

\section{Role of thermal spray OEM and service providers}

Thermal spray OEM industries play a pivotal role in recommending and providing the appropriate equipment, powder morphology, chemical composition, choice of gun, and masking material. Powder stabilization in the flame is key to produce parts faster and reduce powder wastage. OEM companies could conduct synergy meetings to have a common ground for equipment recommendations with climate change

Table 1 Critical raw material share of being utilized in the coating process

\begin{tabular}{|c|c|c|c|c|c|c|c|c|c|c|}
\hline & $\mathrm{Fe}[16]$ & Ni[17] & $\mathrm{Cr}[18]$ & $\mathrm{Al}[19]$ & $\mathrm{Y}[20]$ & $\operatorname{Zr}[21]$ & $\mathrm{Zn}[22]$ & $\mathrm{Co}[23]$ & $\mathrm{W}[24]$ & $\mathrm{Mo}[25]$ \\
\hline Coating & $<2-3 \%$ & $7-12 \%$ & $5-10 \%$ & $<7 \%$ & $20-25 \%$ & $47 \%$ & $50-52 \%$ & $<2 \%$ & $15-20 \%$ & $<5 \%$ \\
\hline Other processes* & $98 \%$ & $79-86 \%$ & $77 \%$ & $93 \%$ & & & $34 \%$ & $14-16 \%$ & $40-50 \%$ & $74 \%$ \\
\hline Batteries & & $2 \%$ & & & & & & $42 \%$ & & \\
\hline Pigments & & & $2-4 \%$ & & & & & & & \\
\hline Refractories & & & & & $30 \%$ & $17 \%$ & & & & \\
\hline Phosphor & & & & & $20 \%$ & & & & & \\
\hline Others & $10-20 \%$ & $5-12 \%$ & & & $20-25 \%$ & & $3 \%$ & & $30 \%$ & $21 \%$ \\
\hline
\end{tabular}

*Casting/alloying/forging/sheet metal/foil/other structural. 

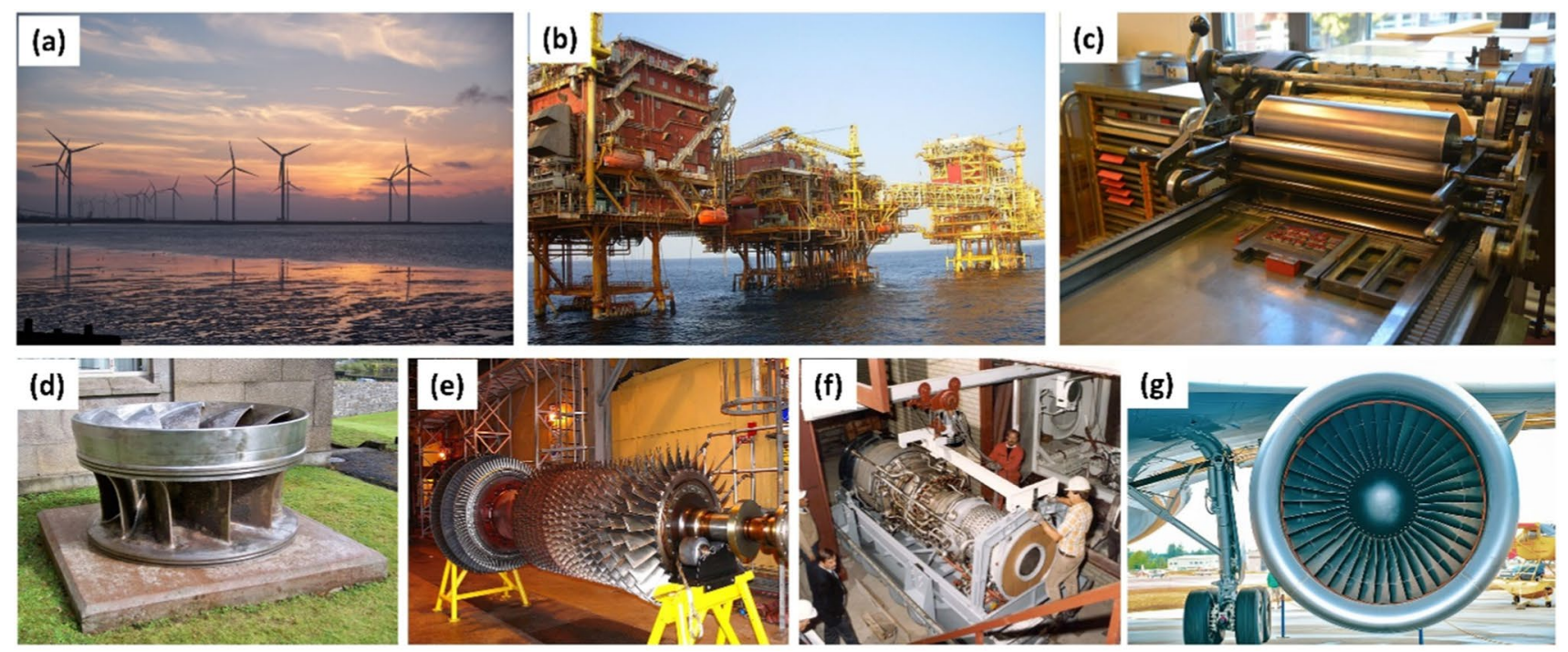

Fig. 7 Role of thermal spray in a wind turbines [26] (thermal sprayed aluminum/zinc), b oil and gas drilling (HVOF) [27], c paper and food industry rolls [28] (HVOF), d hydro turbine Francis runners [29]

in mind and market products with an environmental mindset. A lot of wastage also happens in using OEM-recommended parameters since they may not meet the microstructure and other strength requirements due to on-site conditions. Hence, it is important for OEMs to recommend and depute on-site consultants to speed up the parameter development without much wastage of raw materials. Thermal spray powder manufacturing industries have innovated and produced several powder morphologies to suit the requirements of its customers. The morphology and size play an important role in the energy input and coating quality. Figure 8 shows a glimpse into the morphology of typical thermal spray powders. Ceramic powders are mostly agglomerated and sintered. To increase the heat input and get better deposition efficiency, Oerlikon Metco's patented HOSPTM (hollow oven spherical process) process is useful. Cermets are sintered and crushed or fused and crushed. Wire drawn and swaged or filled feedstock is useful to wire arc coating or flame spray coating. Spheroidal shape particles are easier to melt and flow. Therefore, this helps to drive up the deposition efficiency. However, for the powder manufacturing industries, this means spending energy on melting the raw materials and using gas or water to atomize the droplets. Therefore, the net energy spent on the process from powder making to end of coating process would remain the same.

The HVOF process could be run with clean fuel. However, coating of internal diameters of parts with HVOF would be challenging. The efforts of several companies [34] have led to the development of an ID HVOF gun to coat the internal spaces of parts that are otherwise not accessible
(HVOF), e gas turbines [30], $\mathbf{f}$ land and marine engines [31], $\mathbf{g}$ aero engines [32], e-g TBC, HVOF, flame spray, wire arc spray

with the HVOF process guns. Thermal spray is also popular to coat solar energy photovoltaic cells [35] for improving the dielectric strength of the cells.

Another important aspect of thermal spray is the right choice of chemistry and selection of spray gun and equipment for a particular application. Optimizing this combination is very important to save energy, raw materials, and a faster turnaround time for coating parts.

The role of OEM equipment manufacturers to simplify the functionality of feeders, guns, and prolong the life of spare parts will greatly help to reduce the cost as well as the machining waste. Fluidized bed feeders are expensive and have a lot of electronics involved, and wheel feeders could be quite effective to precisely start and stop the powder flow thereby preventing powder wastage during stabilization of powder flow. Also, maintenance cost of the wheel powder feeders is way too low compared to fluidized bed feeders.

Lanthanated and thoriated electrodes can help to increase its life, and companies need to optimize the amount of thorium and lanthanum in the tungsten electrode to prolong the life of the electrodes. This may not be in the business interest of these companies, but an early correction of this marketing culture would help to reduce waste.

Prolonged use of gun hardware such as nozzle and electrodes could be another option. Companies could be innovative to an insert approach to the damaged portion of the coating gun nozzles, electrodes instead of swapping out the entire nozzle/electrode with a new set.

Waste management in thermal spray industries is crucial. The seven wastes that we typically see in manufacturing

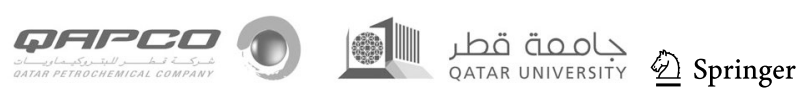




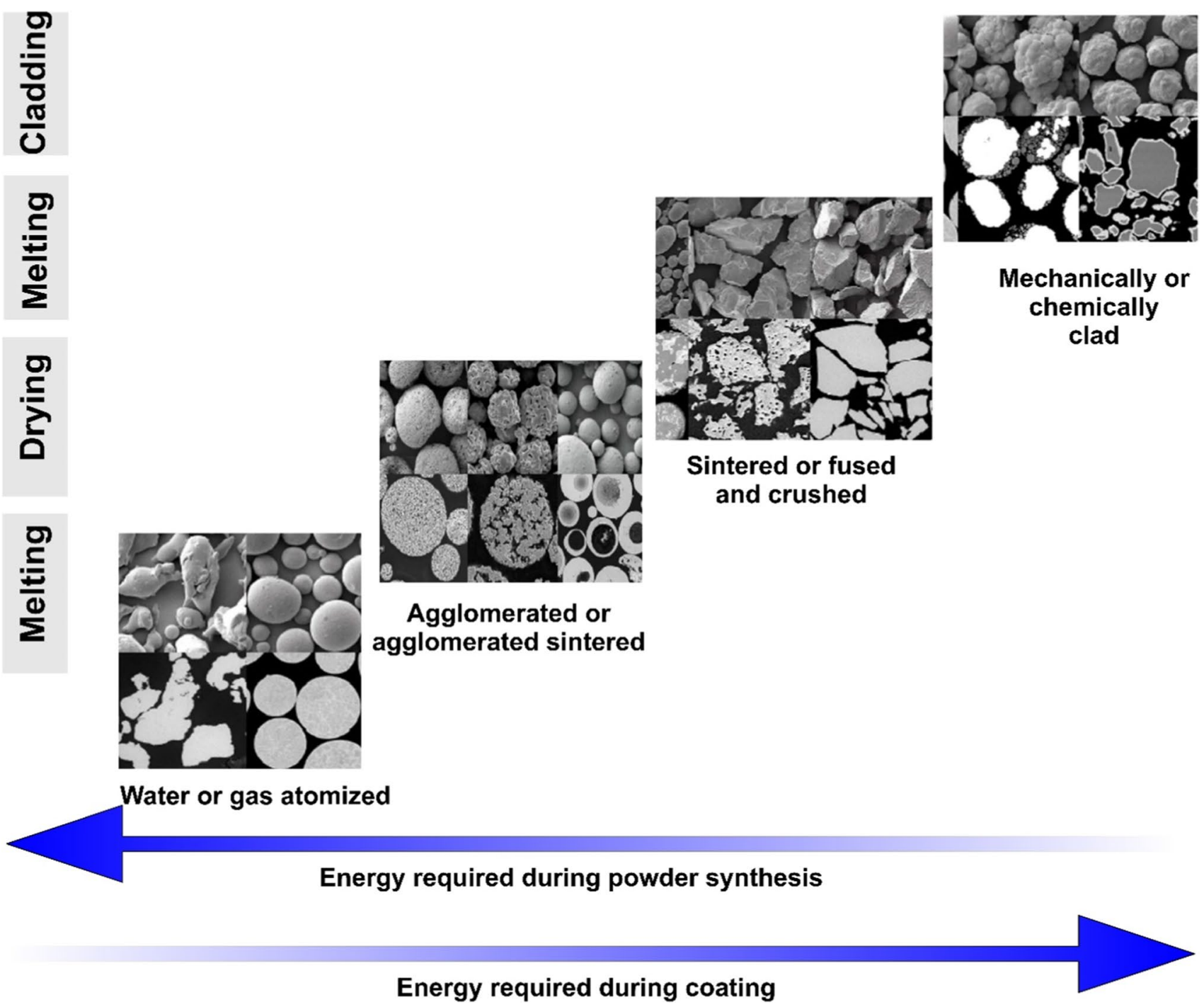

Fig. 8 Powder synthesis [33] and thermal spray process compliment each other in terms of energy usage. If energy is spent on powder making, less energy is spent on the coating process and vice versa.
Particle size range varies from 5 to 200 microns depending on the material and process (extracted from Oerlikon Manual)

storage of parts during manufacturing which are all covered in Made Smarter manufacturing initiative in the UK.

\section{Contribution of academia and research}

The role of material scientists and engineers to contribute to this initiative is immense. Coatings are meant to cater for several applications, for example, thermal protection, corrosion resistance, oxidation resistance, wear resistance, and dimensional restoration about naming a few. So, the composition of the coating is decided based upon these requirements.

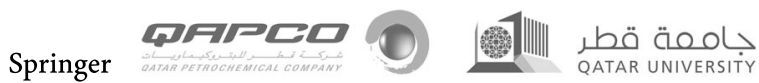


Yttrium ( $\mathrm{Y}$ ) has been included in the shortage of critical raw material [8] by the European Union during 2020-2021. 8YSZ ( $8 \% \mathrm{Y}_{2} \mathrm{O}_{3}$-stabilized zirconia) is the most widespread thermal barrier coating at the moment. Zirconium oxide undergoes a phase change from monoclinic to tetragonal to cubic during melting and from cubic to tetragonal to monoclinic during solidification. $\mathrm{ZrO}_{2}$ cannot stand the volumetric change during the phase change and may lose structural integrity during coating. Usually, $\mathrm{Y}_{2} \mathrm{O}_{3}$ is doped to the $\mathrm{ZrO}_{2}$ coating to stabilize the higher temperature phase.

A research group [36] at Solar Turbines Inc. in collaboration with Solution Spray Technologies LLC Mansfield CT developed a liquid feedstock from yttrium aluminum garnet (YAG), commonly used in laser sources, to be able to deposit thermal barrier coatings by the solution precursor plasma spray method. This will reduce the need to mine $\mathrm{Y}$ and recycle YAG from used lasers. Tungsten is a rare element, and efforts are being made to salvage $\mathrm{W}$ for thermal spray through various means. One such effort [37] has been to recycle WC-Co directly from used cutting tools using a zinc melt method. Bond coats for thermal barrier coatings are typically sprayed with HVOF process through propane, propylene, or kerosene. Cold spray is an option to try to get dense bond coats for gas turbine applications [38]. Altering the chemistry of coatings could sometimes go hand in hand with achieving the twin objectives of resolving the raw material issue and as well as improving the coating performance. One such application is to reduce the thermal conductivity of the thermal barrier coating by not using $\mathrm{Y}$ and utilizing doping of $\mathrm{ZrO}_{2}$ with $\mathrm{Nd}, \mathrm{Gd}$, or $\mathrm{Yb}$ [39]. The key to achieving low conductivity is to provide as much barrier to heat conduction by way of inducing defects such as porosity, heavier ions.

Traditional chemistry of typical coating compositions such as $8 \mathrm{YSZ}$, WC-Co, NiCrAlY, and CoMoCrSi has been challenged not only to improve the performance of the coating but also in dealing with the raw material shortage. One such approach [40] is to increase the life of bond coat systems in the coating so the service life of the coated parts could be prolonged. If the end properties are similar or better and achieved with less emissions, there is significant contribution to combating climate change. In addition to the coating itself, there are a lot of auxiliary materials such as masking tape and compounds that are sensitive to the environment. Metal masking could be a better option compared to using masks with thermosetting resins and glass fibers which end up at the landfill after coating. Looking at the gun design and ways and means to utilize the entire energy of the spray gun could not only improve the deposition efficiency of the coatings [41], but also significantly reduce the production time of parts.
Additive manufacturing [42] and thermal spray could be complemented to achieve the end objectives of coatings. Powder particles could have a common morphology and size for dual usage in additive manufacturing or coating. Akedo and Shinoda [43] discussed the potential of using aerosol deposition method to coat non-heavy-duty applications such as semiconductors and solar cells. This technology is said to have to low-energy footprint and low cost compared to other thin-film coating technologies. Controlling the voltage fluctuation and improving the anode and cathode life is important to reduce the energy consumption during plasma spray and many nozzles have been designed to optimize the plasma spray process [44].

The traditional process of using cold spray coat transition elements like $\mathrm{Al}$ and $\mathrm{Cu}$ could be extended to heavy elements like $\mathrm{Ni}$, and even additive manufacturing using cold spray [45] is a much-discussed topic in the industrial community as well. Few elements that could be sprayed with cold spray are $\mathrm{Al}, \mathrm{Cu}, \mathrm{Ni}, \mathrm{Ti}, \mathrm{Ag}, \mathrm{Zn}, \mathrm{Ta}$, and $\mathrm{Nb}$ and their alloys as well as composites such as $\mathrm{Cu}-\mathrm{W}, \mathrm{Al}-\mathrm{SiC}$, and $\mathrm{Al}-\mathrm{Al}_{2} \mathrm{O}_{3}$.

\section{Digitalization of thermal spray}

In the past two decades, much research has emerged into in situ diagnostics like velocity and temperature measurement of the particles during coating processes [46]. The process parameters such as gas flows, carrier gas flows, and the feed rate can correct themselves based on the feedback from the particles. The specimen temperature while coating can be fed into the controller to adjust the spray distance or cooling methods to keep the part temperature low [47]. Contact (thermocouple based) and noncontact (infrared based) temperature measurement devices are available for this process to be incorporated for online monitoring as well as self-adjustment. A research group at SUNY [48] have done a lot of work on in situ residual stress measurement as the coating build upon the substrate. Upon arriving at the threshold stress, or stress corroborated thickness, the process can auto stop to avoid spallation. Residual stress analysis could also be used for freeform part manufacturing as well, so the part gets detached from the base material and can be used as a freeform shape [40].

Artificial intelligence (AI) and machine learning [49] have gained prominence in other sectors and thermal spray can be part of this change to reduce emissions and wastage. It remains to be seen how OEMs can integrate the work on closed-loop feedback, in situ stress measurement, and robot interfacing to create intelligent thermal spray machines. Data analytics could be an integral part of thermal spray, and governing bodies may soon mandate industries to give them the emissions and waste data. Diagnostics are also being introduced for suspension precursor processing which is useful to monitor the diagnostics

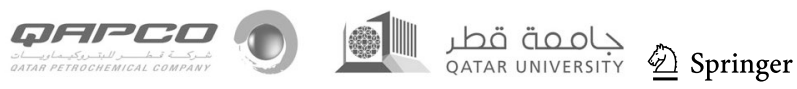


of the particles in the liquid state [50]. This could enhance the deposition efficiency of the solution precursor coatings. Data collection and analysis could be a seamless part of the thermal spray facility. It would be imperative to collect and report data to governing bodies in this format in the near future. Handheld $\mathrm{X}$-ray fluorescence (XRF) could be integrated to the thermal spray dust collection chutes to monitor the discarded elements. Similarly, direct-write coating technologies are available to monitor the coated part temperature during service. They could help determine the creep life of specimens during service and calculate the life cycle of the components [51]. Figure 9 shows a thermal spray layout that is typical in industries and academia, enabled with multi-sensors and wastage collector. The efforts to cut down waste and switch to energy-efficient processes start with data collection. From Fig. 9, it can be inferred that sensors can be mounted at strategic locations of the booth to collect the data. Two types of data can be collected, namely, (i) the process data such as particle velocity and temperature that will help to optimize in real time, the gun parameters, robot speed, and process gas flows and (ii) resources used and wastage data that can be presented to governing bodies. Based on the percentage waste generated in each category (shown later in Table 3), it would help categorize the industries as green, yellow, or red in terms of emission and help in strongly monitoring the compliance with climate change objectives. The data collection can be linked to servers and accessed live through cloud computing. Mathematical models could be built to optimize the fuel/oxygen ratio of any combustion spray process to find the optimized mix to melt the particles and reduce fuel consumption and drive up the deposition efficiency of the process [52]. Machine learning could assist to seamlessly learn and modify robot paths during coating to determine the best move for efficient coating [53].

\section{Hybrid technologies}

Hybrid processes could be used in conjunction with one another or one after another to achieve the results. For example, a laser sweep on the HVOF WC-Co-coated part could further densify the coating, resulting in better wear resistance. In addition, businesses with several processing techniques under one roof could tap the potential of hybrid processes to achieve speed and cut down on waste thereby enhancing performance and durability of the coatings. CSAM is one such process where many hybrid processes upstream or downstream have been developed to aid to the coating properties. Stresses developed during CSAM can be modified by shot peening [54]. Laser ablation on plasmasprayed coatings could help densify the coating thereby enhancing properties [55]. The process of cold spray with friction stir welding has been tapped to weld dissimilar metal like $\mathrm{Mg}$ and $\mathrm{Al}$ [56]. Similarly, properties such as fatigue performance is a critical consideration for rotating parts. It has been observed that an improvement in fatigue life is obtained when the specimen is surface treated by shot peening prior to the CSAM process [54]. In addition, the cold spray coating of Ti-6Al-4 V followed by hot isostatic pressing improves the density and ductility of the coating [57]. The CSAM process involves heating the gas before coating to 800 or $1000{ }^{\circ} \mathrm{C}$ to excite the gas molecules. One research pointed out that gas heating or usage of helium gas could be eliminated if the surface is laser treated prior to the CS deposition [58].

Orthopedic implant production is a growing market, where implants of Ti-6Al-4 V are manufactured by casting. Alternatively, additive manufacturing (AM) of the implants followed by electron beam melting (EBM) or selective laser melting (SLM) can control the porosity [59]. Thus, there is a potential to
Fig. 9 Thermal spray future on digitalization. Red dots reveal digital input data collection leading to digital output to robot and guns. (1, robot; 2 , powder feeder; 3, process control; 4, specimen controller and holder; 5, X-ray detector; 6, waste powder collector; 7 , powder velocity and temperature sensor (Spray watch $^{\mathrm{TM}}$, DPV ${ }^{\mathrm{TM}}$, Accuraspray ${ }^{\mathrm{TM}}$ connected to feedback loop); 8, feed lines; 9, plasma torch and plasma flame)

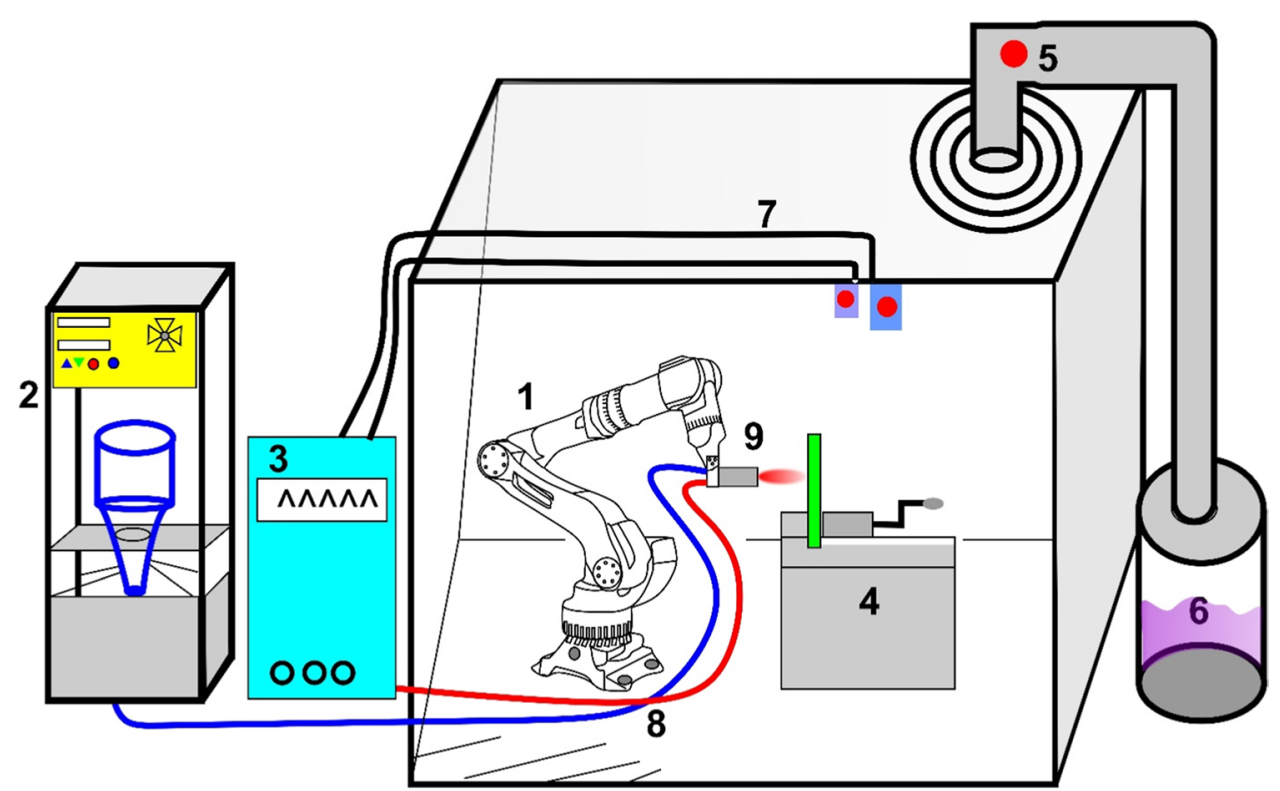


Table 2 Some of the hybrid technologies tried for different coating chemistries

\begin{tabular}{|c|c|c|c|c|c|c|c|c|}
\hline Material & $\begin{array}{l}\mathrm{TS}+\text { micro } \\
\text { wave heating }\end{array}$ & $\begin{array}{l}\text { TS + cryo- } \\
\text { genic treat- } \\
\text { ment }\end{array}$ & Cold spray additive & $\begin{array}{l}\text { TS pow- } \\
\text { der + TS } \\
\text { precursor }\end{array}$ & $\begin{array}{l}\mathrm{TS}+\text { laser } \\
\text { treatment }\end{array}$ & CS + shot peen & $\mathrm{CS}+\mathrm{SLM}$ & $\begin{array}{l}\text { Hybrid } \\
\text { aerosol } \\
\text { deposition }\end{array}$ \\
\hline WC-Co & & {$[60]$} & {$[61]$} & & & {$[54]$} & & \\
\hline MCrAlY & & & {$[38]$} & & {$[62]$} & & & \\
\hline $\mathrm{Al}_{2} \mathrm{O}_{3}$ & {$[63]$} & & & & & & & [43] \\
\hline 8YSZ & {$[64]$} & & & {$[65,66]$} & & & & \\
\hline Co based & [67] & & & & {$[68]$} & & & \\
\hline Metals or alloys & & & {$[42,57,69]$} & & & [69] & [45] & \\
\hline
\end{tabular}

use thermal spray to deposit hydroxyapatite on additive manufactured implants to enhance the bioactivity of the implants.

A host of hybrid processes that have been trialed for several material systems is summarized in Table 2. The material types mentioned spans industries from power generation to aviation and healthcare that are actively looking for lowenergy input processes to support their product line.

\section{Life cycle sustainability assessment across the triple bottom line}

The environmental impact of any industrial process will take prominence over its economic aspects due to the overall impact the climate will have on the economy. Countries will start paying attention to the macro-economic repercussions due to climate change rather than just focusing on the impact of one industry on the economy. Just like any other manufacturing process, thermal spray needs raw materials and generates wastes. With the focus shifting on the circular economy, it is important to quantify and track the resources and waste through life cycle sustainability assessment for maximized sustainability across the triple bottom line (environment, economic, and social aspects). It analyzes the inventory of the process and waste and evaluates the potential environmental impact. This is achieved by identifying the scope of the project, analysis of the inventory, environmental impact assessment, and putting it in a simple form for correct analysis.

A study of life cycle assessment comparison of electroplating and other thermal spray processes has been reported [70]. The waste powders collected from the dust collection system or salvaged from the old coatings could be recycled innovatively [71]. Table 3 shows a typical data collection example for organizations to enable life cycle assessment. The data collected in such a manner could help

Table 3 Data collection in industries would be mandatory to operate, and digitalization tools can help to collect data seamlessly (an example format only, not representative of any company)

\begin{tabular}{|c|c|c|c|c|c|c|}
\hline \multicolumn{7}{|c|}{ Solid waste management $(\mathrm{kg})$} \\
\hline Metal alloy & Powder used today & Powder used YTD & $\begin{array}{l}\text { Coating } \\
\text { weight YTD }\end{array}$ & Dust composition & Waste today & Waste YTD \\
\hline WC-Co & 10 & 120 & 75 & WC-Co & 3 & 45 \\
\hline NiCrAlY & 30 & 3000 & 1800 & NiCrAlY & 12 & 1200 \\
\hline CoMoCrSi & 20 & 1000 & 700 & $\mathrm{CoMoCrSi}$ & 8 & 300 \\
\hline $\mathrm{Al}_{2} \mathrm{O}_{3}$ & 450 & 4800 & 3000 & $\mathrm{Al}_{2} \mathrm{O}_{3}$ & 150 & 1800 \\
\hline $\mathrm{Y}_{2} \mathrm{O}_{3}-\mathrm{ZrO}_{2}$ & 120 & 1500 & 60 & $\mathrm{Y}_{2} \mathrm{O}_{3}-\mathrm{ZrO}_{2}$ & 60 & 700 \\
\hline \multicolumn{3}{|c|}{ Fuel and Consumables Spent } & \multicolumn{4}{|c|}{ Landfill Waste (kg) } \\
\hline Gases & Today (M3) & YTD (M3) & & & Weight today & Weight YTD \\
\hline Hydrogen & 400 & 4500 & & Masking Tape & 120 & 1300 \\
\hline Oxygen & 200 & 2200 & & Silicon O Rings & 5 & 45 \\
\hline Acetylene & 100 & 800 & & Silicon Masks & 8 & 80 \\
\hline Kerosene & 100 & 1000 & & Delrin Insulator & 10 & 120 \\
\hline Nitrogen & 100 & 2000 & & & & \\
\hline Consumables & Today $(\mathrm{kg})$ & YTD (kg) & & & kWh Today & kWh YTD \\
\hline Copper Nozzle & 3 & 30 & & Power & 1200 & 54,000 \\
\hline W electrode & 4 & 40 & & & & \\
\hline
\end{tabular}


create discrete information on the damage made to the ecosystem, human health, and resources such as raw materials which would help the companies to achieve regulatory compliance.

Powder deposition typically is about $50-60 \%$ efficient, which means $40 \%$ is generated as waste either at the landfill or to the recycling units. The requirement of segmented thermal barrier coatings is inevitable in some high-temperature gas turbines, and it is possible to achieve this with a powder feedstock, solution precursor method, or suspension precursor method [72]. Powder methods can yield more throughput, but a high-energy process is needed while solution or suspension precursor spray yields less throughput than the powder method but low energy.
Life cycle assessment for solution precursor plasma spray [73] compared to the conventional powder feedstock spray provides enormous information and an accurate idea about adopting the SPS method for industries like power generation wherein high-throughput coating is needed due to the large volume of parts and high surface area to be coated. Solid waste like polymer or resin masks have no choice but to go to landfill. Metal masks are useful from a recycling point of view, but intricate masking is difficult with metal masks. Hence, environmentally friendly masks need to be innovated to support the thermal spray industry.

Figure 10 shows the major contributors to the Greenhouse gases $(\mathrm{GhG})$ i.e., methane, carbon dioxide, nitrous oxide etc.

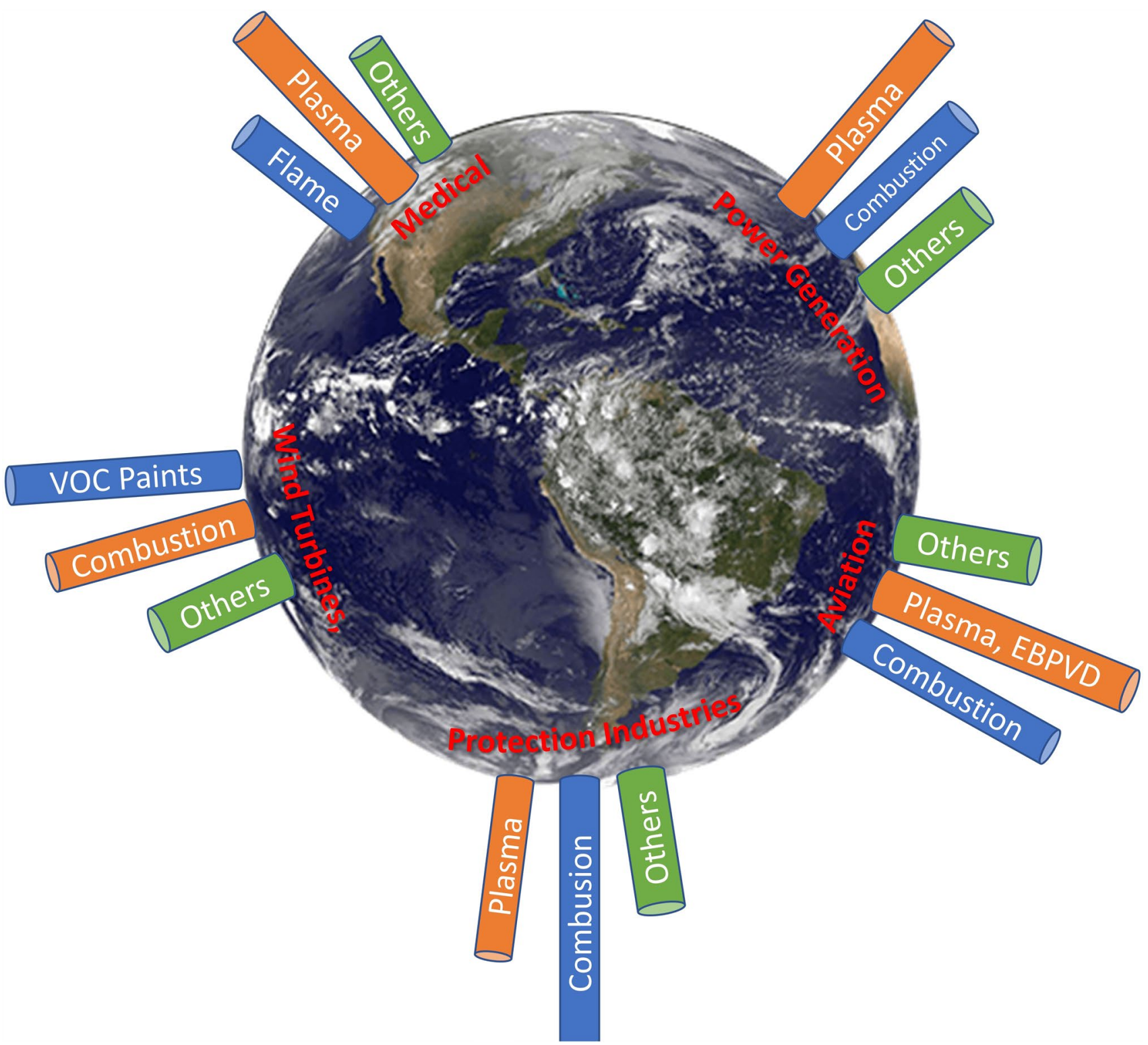

Fig. 10 Process and industry's contribution to greenhouse gas emissions

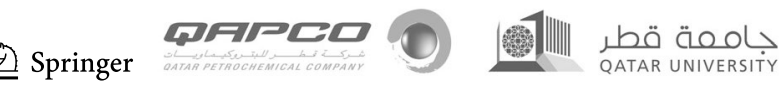


in top five sectors who use thermal spray. Plasma is the major source of emission in the aviation and power generation industry. Oil and gas industries mostly use hydrocarbons to coat their drilling equipment, and hence combustion products are their source of emissions. Wind turbine industries emit a lot of VOC during the blade manufacturing and painting process.

\section{Conclusions and outlook}

Thermal spray can bring improved lean/productivity to other manufacturing processes and prolong the life cycle of the parent material. When assisted with other processes such as additive manufacturing, thermal spraying reduces the energy consumption and raw material usage. Both thermal spray OEMs and service providers need to embrace the culture of durability as much as possible to minimize waste and recycle the critical raw materials. Digitalization of the thermal spray industry would help gather more data on raw material usage and wastage which can benefit Governments to incentivize companies operating with low greenhouse gas emission (GhG) gases such as methane, carbon dioxide and nitrous oxide to name a few. A manufacturing process with higher green house gas $(\mathrm{GhG})$ emissions would cause trapping of heat in the atmosphere which would warm the planet and melt the glaciers and hence a manufacturing process with low GhG emissions is much desirable. For this reason, a new branch of spraying namely cold spray additive manufacturing (CSAM) has now started to gain more popularity due to having low GhG as opposed to traditional variants of thermal spray. Thus, ambitious manufacturing inventions in the spray field including the development of hybrid techniques will pave the way to innovate new advances in this area which can capitalise the power of data collection and be benefitted by the power of machine learning. The review shows how the adoption of thermal spray in various fields of manufacturing can cut the reliance on some of the critical raw materials (CRMs) and help fight the noble cause of controlling climate change in an uncertain period looming the globe.

Funding This work received financial support provided by the UKRI via Grants No. EP/L016567/1, EP/S013652/1, EP/S036180/1, EP/ T001100/1, and EP/T024607/1; TFIN + Feasibility study award to LSBU (EP/V026402/1), the Royal Academy of Engineering via Grants No. IAPP18-19\295 and TSP1332; EURAMET EMPIR A185 (2018); the EU Cost Action (CA15102, CA18125, CA18224, and CA16235); and the Newton Fellowship award from the Royal Society (NIF) R1\191571). Financial support was also received from the European Regional Development Funds (ERDF)-sponsored A2i project at LSBU that has catalyzed several industrial partnerships. Wherever applicable, the work made use of Isambard Bristol, UK, supercomputing service accessed by a Resource Allocation Panel (RAP) grant as well as ARCHER resources (Project e648).
Data availability As this is a review paper, no new data was generated.

\section{Declarations}

Conflict of interest The authors declare no competing interests.

Open Access This article is licensed under a Creative Commons Attribution 4.0 International License, which permits use, sharing, adaptation, distribution and reproduction in any medium or format, as long as you give appropriate credit to the original author(s) and the source, provide a link to the Creative Commons licence, and indicate if changes were made. The images or other third party material in this article are included in the article's Creative Commons licence, unless indicated otherwise in a credit line to the material. If material is not included in the article's Creative Commons licence and your intended use is not permitted by statutory regulation or exceeds the permitted use, you will need to obtain permission directly from the copyright holder. To view a copy of this licence, visit http://creativecommons.org/licenses/by/4.0/.

\section{References}

1. A. S. M. Ang and C. C. Berndt, "A review of testing methods for thermal spray coatings," International Materials Reviews, vol. 59, no. 4. Maney Publishing, pp. 179-223, 2014. https://doi.org/10. 1179/1743280414Y.0000000029.

2. G.A. Kool, Current and future materials in advanced gas turbine engines. J. Therm. Spray Technol. 5(1), 31-34 (1996). https://doi. org/10.1007/BF02647514

3. S. Kuroda, J. Kawakita, M. Watanabe, and H. Katanoda, "Warm spraying - a novel coating process based on high-velocity impact of solid particles," Science and Technology of Advanced Materials, vol. 9, no. 3. Taylor \& Francis, p. 17, Jul. 01, 2008. https:// doi.org/10.1088/1468-6996/9/3/033002.

4. P. G. Lashmi, P. v. Ananthapadmanabhan, G. Unnikrishnan, and S. T. Aruna, "Present status and future prospects of plasma sprayed multilayered thermal barrier coating systems," Journal of the European Ceramic Society, vol. 40, no. 8. Elsevier Ltd, pp. 2731-2745, Jul. 01, 2020. https://doi.org/10.1016/j.jeurceramsoc. 2020.03.016.

5. "Use of energy in industry - U.S. Energy Information Administration (EIA)." https://www.eia.gov/energyexplained/use-of-energy/ industry.php (accessed Jun. 26, 2021).

6. "Thermal spray coatings market global forecast to 2025 । MarketsandMarkets." https://www.marketsandmarkets.com/MarketReports/thermal-spray-coating-market-181347083.html?gclid= Cj0KCQjwnueFBhChARIsAPu3YkRYQ5QcM5xhEom2uYUCp tDLiieDp13-LtFdDOmACPkRoFaOYUtEHY8aAhd7EALw_wcB (accessed Jun. 12, 2021).

7. "Thermal barrier coatings market to reach USD 25.82 Billion By 2027 I CAGR of 4.9\%: Reports And Data." https://www.prnew swire.com/news-releases/thermal-barrier-coatings-market-toreach-usd-25-82-billion-by-2027--cagr-of-4-9-reports-and-data301160710.html (accessed Jun. 13, 2021).

8. "Cold spraying I part of thermal spraying." https://impact-innov ations.com/en/technology/ (accessed Jun. 26, 2021).

9. "Thermal spray market global industry size, share analysis I A \&." https://www.openpr.com/news/1166238/thermal-spray-market-global-industry-size-share-analysis-a-a-thermal-spray-coati ngs-u-s-flame-spray-coating-company-u-s-general-magnaplatecorporation-u-s-praxair-surface-technologies.html (accessed Jun. 20, 2021).

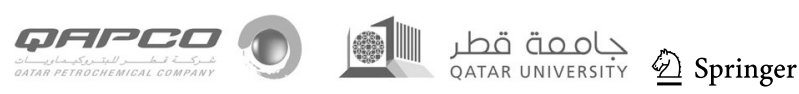


10. "Thermal spray coatings market size, share and industry analysis - 2024." https://www.gminsights.com/industry-analysis/ thermal-spray-coating-market?gclid $=\mathrm{Cj} 0 \mathrm{KCQjwnueFBhC}$ hARIsAPu3YkTv1OpTnrwPBlcUT1rUSZq44J5r2NM6BNQn SIkp6FZ7IEXTgenPyx4aAmycEALw_wcB (accessed Jun. 12, 2021).

11. "Use of energy in industry - U.S. Energy Information Administration (EIA)." https://www.eia.gov/energyexplained/use-ofenergy/industry.php (accessed Jun. 12, 2021).

12. J. L. Smialek and R. A. Miller, "Revisiting the birth of 7YSZ thermal barrier coatings: Stephan stecura," Coatings, vol. 8, no. 7. MDPI AG, p. 255, Apr. 01, 2018. https://doi.org/10.3390/ coatings 8070255 .

13. "JODI oil dataset, monthly update - knoema.com." https:// knoema.com/JODIOIL2018/jodi-oil-dataset-monthly-update (accessed Jul. 03, 2021).

14. V. v. Popov et al., "Powder bed fusion additive manufacturing using critical raw materials: a review," Materials, vol. 14, no. 4, pp. 1-37, Feb. 2021, https://doi.org/10.3390/ma14040909.

15. P. W. Schilke, "GER-3569G - advanced gas turbine materials and coatings," 1995.

16. "Iron ore facts." https://www.nrcan.gc.ca/our-natural-resources/ minerals-mining/minerals-metals-facts/iron-ore-facts/20517 (accessed Jul. 01, 2021).

17. "LARCO GMMSA - nickel." http://www.larco.gr/nickel.php (accessed Jun. 12, 2021)

18. Panda Subrakant, "Overview of chromium industry," 2015. Accessed: Jun. 12, 2021. [Online]. Available: www.imfa.in

19. "22.1 The Elements of Group 13 - Chemistry LibreTexts." https://chem.libretexts.org/Bookshelves/General_Chemistry/ Book\%3A_Chemistry_(Averill_and_Eldredge)/22\%3A_The_pBlock_Elements/22.1_The_Elements_of_Group_13 (accessed Jul. 01, 2021).

20. "GLOBAL YTTRIUM MARKET," 2021, Accessed: Jun. 12, 2021. [Online]. Available: www.mordorintelligence.com

21. "The application of zirconium products." https://www.samat erials.com/content/the-application-of-zirconium-products.html (accessed Jun. 12, 2021).

22. "Zinc." https://www.essentialchemicalindustry.org/metals/zinc. html (accessed Jun. 12, 2021).

23. "Panasonic decreases cobalt content of its batteries - The Green Optimistic." https://www.greenoptimistic.com/panasonic-decre ases-cobalt-content-of-its-batteries-20180726/ (accessed Jun. 12, 2021).

24. "Tungsten carbide powder market size - trend report 2018 major." https://www.openpr.com/news/1136896/tungsten-carbide-powdermarket-size-trend-report-2018-major-players-sandvik-ab-kenna metal-federal-carbide-company-guangdong-xianglu-tungstennanchang-cemented-carbide-japan-new-metals-china-tungstenreade-international-corp-and-merck-kgaa.html (accessed Jun. 12, 2021).

25. "What are the uses of molybdenum." https://www.samaterials. $\mathrm{com} /$ content/what-are-the-uses-of-molybdenum.html (accessed Jun. 12, 2021).

26. "Free Images : wind turbine, wind farm, windmill, sky, water, atmospheric phenomenon, cloud, morning, atmosphere, evening, machine, sea, sunset, calm, horizon, sunlight, afterglow, public utility, dusk, landscape, reflection, ocean, dawn, electricity 5747x3832 - 1534669 - Free stock photos - PxHere.” https:// pxhere.com/en/photo/1534669 (accessed Aug. 27, 2021).

27. "File:ONGC Oil Platform.jpg - Wikimedia Commons." https:// commons.wikimedia.org/wiki/File:ONGC_Oil_Platform.jpg (accessed Aug. 27, 2021)

28. "silver, industrial, machine, indoor, technology, pressure, lead set, printing, barmbek, museum of the work I Pxfuel." https://www. pxfuel.com/en/free-photo-ojbnv (accessed Aug. 27, 2021).
29. "Geograph:: Francis turbine runner, Sloy Hydro... (C) James T M Towill cc-by-sa/2.0".

30. "generator, turbine, power station, repair, industry, factory, equipment, machinery, metal, indoors I Pxfuel." https://www.pxfuel. com/en/free-photo-odjhp (accessed Aug. 27, 2021).

31. "File:Installation of a LM2500 gas turbine.JPG - Wikimedia Commons." https://commons.wikimedia.org/wiki/File:Installati on_of_a_LM2500_gas_turbine.JPG (accessed Aug. 27, 2021).

32. "jet engine, aviation, aircraft, plane, jet, engine, airplane, technology, aerospace, airport I Pxfuel." https://www.pxfuel.com/en/ free-photo-xgkhm (accessed Aug. 27, 2021).

33. "Oerlikon Metco Thermal Spray Materials Guide," 2018.

34. "Tungsten carbide internal pipe coating HVOF equipment \& service." https://kermetico.com/convertible/hvof-id-coating-thermalspray-gun-for-wear-protection-of-internal-pipe-surfaces (accessed Jun. 18, 2021).

35. "Solar energy thermal spray coating I A\&A Thermal Spray Coatings." https://www.thermalspray.com/industries/solar-energy/ (accessed Jun. 18, 2021).

36. U. States Department of Energy, "Ultra-high temperature thermal barrier coating development and validation benefits for our industry and our nation."

37. E. Altuncu, F. Ustel, A. Turk, S. Ozturk, and G. Erdogan, "E. ALTUNCU et al.: CUTTING-TOOL RECYCLING PROCESS WITH THE ZINC-MELT METHOD CUTTING-TOOL RECYCLING PROCESS WITH THE ZINC-MELT METHOD FOR OBTAINING THERMAL-SPRAY FEEDSTOCK POWDER (WC-Co) POSTOPEK RECIKLIRANJA ORODIJ ZA REZANJE Z METODO TALJENJA V Zn ZA PRIDOBIVANJE PRAHU WC-Co ZA TERMI^NO NABRIZGAVANJE."

38. D.L. Guo, D. MacDonald, L. Zhao, B. Jodoin, Cold spray MCrAlY coatings on single-crystal superalloy using nitrogen: properties and economics. J. Therm. Spray Technol. 29(7), 16281642 (2020). https://doi.org/10.1007/s11666-020-01058-x

39. C.U. Hardwicke, Y.C. Lau, Advances in thermal spray coatings for gas turbines and energy generation a review. J Therm Spray Technol 22(5), 564-576 (2013). https://doi.org/10.1007/ s11666-013-9904-0

40. A. Sato, H. Harada, and K. Kawagishi, "Communications development of a new bond coat 'EQ Coating' System."

41. J. Schein, J. Zierhut, M. Dzulko, G. Forster, K.D. Landes, Improved plasma spray torch stability through multi-electrode design. Contrib. Plasma Phys. 47(7), 498-504 (2007). https:// doi.org/10.1002/ctpp.200710064

42. S. Yin et al., "Cold spray additive manufacturing and repair: fundamentals and applications," Additive Manufacturing, vol. 21. Elsevier B.V., pp. 628-650, May 01, 2018. https://doi.org/10. 1016/j.addma.2018.04.017.

43. J. Akedo, "Room temperature impact consolidation (RTIC) of fine ceramic powder by aerosol deposition method and applications to microdevices," Journal of Thermal Spray Technology, vol. 17, no. 2. Springer, pp. 181-198, Jun. 18, 2008. https://doi.org/10.1007/ s11666-008-9163-7.

44. A. Vardelle et al., "The 2016 thermal spray roadmap," Journal of Thermal Spray Technology, vol. 25, no. 8. Springer New York LLC, pp. 1376-1440, Dec. 01, 2016. https://doi.org/10.1007/ s11666-016-0473-x.

45. S. Yin et al., Hybrid additive manufacture of $316 \mathrm{~L}$ stainless steel with cold spray and selective laser melting: microstructure and mechanical properties. J. Mater. Process. Technol. 273, 116248 (2019). https://doi.org/10.1016/j.jmatprotec.2019.05.029

46. J.R. Fincke, W.D. Swank, R.L. Bewley, D.C. Haggard, M. Gevelber, D. Wroblewski, Diagnostics and control in the thermal spray process. Surf. Coat. Technol. 146-147, 537-543 (2001). https:// doi.org/10.1016/S0257-8972(01)01432-3 
47. H. R. Salimijazi et al., "Measuring substrate temperature variation during application of plasma-sprayed zirconia coatings," Journal of Thermal Spray Technology, vol. 16, no. 4. Springer, pp. 580587, Dec. 04, 2007. https://doi.org/10.1007/s11666-007-9050-7.

48. J. Matejicek, S. Sampath, In situ measurement of residual stresses and elastic moduli in thermal sprayed coatings part 1: apparatus and analysis. Acta Mater. 51(3), 863-872 (2003). https://doi.org/ 10.1016/S1359-6454(02)00478-0

49. R. Sarc, A. Curtis, L. Kandlbauer, K. Khodier, K. E. Lorber, and R. Pomberger, "Digitalisation and intelligent robotics in value chain of circular economy oriented waste management - a review," Waste Management, vol. 95. Elsevier Ltd, pp. 476-492, Jul. 15, 2019. https://doi.org/10.1016/j.wasman.2019.06.035.

50. A. Akbarnozari et al., Online diagnostic system to monitor temperature of in-flight particles in suspension plasma spray. J. Therm. Spray Technol. 29(5), 908-920 (2020). https://doi.org/10. 1007/s11666-020-01045-2

51. J. Longtin, S. Sampath, S. Tankiewicz, R.J. Gambino, R.J. Greenlaw, Sensors for harsh environments by direct-write thermal spray. IEEE Sens. J. 4(1), 118-121 (2004). https://doi.org/10.1109/ JSEN.2003.822218

52. M. N. Khan and T. Shamim, "Effect of operating parameters on a dual-stage high velocity oxygen fuel thermal spray system," Journal of Thermal Spray Technology, vol. 23, no. 6. Springer New York LLC, pp. 910-918, 2014. https://doi.org/10.1007/ s11666-014-0114-1.

53. D. Ikeuchi, A. Vargas-Uscategui, X. Wu, P.C. King, Neural network modelling of track profile in cold spray additive manufacturing. Materials 12(7), 2827 (2019). https://doi.org/10.3390/ma121 72827

54. A. Moridi, S.M. Hassani-Gangaraj, S. Vezzú, L. Trško, M. Guagliano, Fatigue behavior of cold spray coatings: the effect of conventional and severe shot peening as pre-/post-treatment. Surf. Coat. Technol. 283, 247-254 (2015). https://doi.org/10.1016/j.surfcoat. 2015.10.063

55. P. Cheang, K.A. Khor, L.L. Teoh, S.C. Tam, Pulsed laser treatment of plasma-sprayed hydroxyapatite coatings. Biomaterials 17(19), 1901-1904 (1996). https://doi.org/10.1016/0142-9612(95) 00146-8

56. V.K. Champagne, M.K. West, M. Reza Rokni, T. Curtis, V. Champagne, B. McNally, Joining of cast ZE41A Mg to wrought 6061 Al by the cold spray process and friction stir welding. J Therm Spray Technol 25(1-2), 143-159 (2016). https://doi.org/10.1007/ s11666-015-0301-8

57. C. Chen et al., Effect of hot isostatic pressing (HIP) on microstructure and mechanical properties of Ti6Al4V alloy fabricated by cold spray additive manufacturing. Addit. Manuf. 27, 595-605 (2019). https://doi.org/10.1016/j.addma.2019.03.028

58. M. Bray, A. Cockburn, W. O'Neill, The laser-assisted cold Spray process and deposit characterisation. Surf. Coat. Technol. 203(19), 2851-2857 (2009). https://doi.org/10.1016/j.surfcoat. 2009.02 .135

59. S. L. Sing, J. An, W. Y. Yeong, and F. E. Wiria, "Laser and electron-beam powder-bed additive manufacturing of metallic implants: a review on processes, materials and designs," Journal of Orthopaedic Research, vol. 34, no. 3. John Wiley and Sons Inc., pp. 369-385, Mar. 01, 2016. https://doi.org/10.1002/jor.23075.

60. A. Babu, H.S. Arora, R.B. Nair, I. Chakraborty, A. Chauhan, H.S. Grewal, Wear behavior of microwave-annealed and cryogenically treated thermal spray coatings: a comparative evaluation. Materials Today: Proceedings 33, 5348-5353 (2020). https://doi.org/10. 1016/j.matpr.2020.02.985
61. B. Barnett, M. Trexler, V. Champagne, Cold sprayed refractory metals for chrome reduction in gun barrel liners. Int. J. Refract Metal Hard Mater. 53, 139-143 (2015). https://doi.org/10.1016/j. ijrmhm.2015.07.007

62. G. Marginean, D. Frunzăverde, D. Utu, R. Crîsta, W. Brandl, Influence of electron beam and laser remelting on the oxidation behaviour of HVOF-sprayed CoNiCrAlY coatings. BHM BergHuettenmaenn. Monatsh. 152(1), 32-38 (2007). https://doi.org/ 10.1007/s00501-006-0269-2

63. A.K. Sharma, R. Krishnamurthy, Microwave processing of sprayed alumina composite for enhanced performance. J. Eur. Ceram. Soc. 22(16), 2849-2860 (2002). https://doi.org/10.1016/ S0955-2219(02)00051-1

64. C. Zhang et al., Microwave sintering of plasma-sprayed yttria stabilized zirconia electrolyte coating. J. Eur. Ceram. Soc. 28(13), 2529-2538 (2008). https://doi.org/10.1016/j.jeurceramsoc.2008. 03.040

65. S.V. Joshi, G. Sivakumar, T. Raghuveer, R.O. Dusane, Hybrid plasma-sprayed thermal barrier coatings using powder and solution precursor feedstock. J Therm Spray Technol 23(4), 616-624 (2014). https://doi.org/10.1007/s11666-014-0075-4

66. V. Gopal, S. Goel, G. Manivasagam, S. Joshi, Performance of hybrid powder-suspension axial plasma sprayed Al2O3-YSZ coatings in bovine serum solution. Materials 12(12), 1922 (2019). https://doi.org/10.3390/ma12121922

67. C.D. Prasad, S. Joladarashi, M.R. Ramesh, M.S. Srinath, B.H Channabasappa, Influence of microwave hybrid heating on the sliding wear behaviour of HVOF sprayed CoMoCrSi coating. Materials Research Express 5(8), 086519 (2018). https://doi.org/ 10.1088/2053-1591/aad44e

68. Š Houdková, Z. Pala, E. Smazalová, M. Vostř̌ák, Z. Česánek, Microstructure and sliding wear properties of HVOF sprayed, laser remelted and laser clad Stellite 6 coatings. Surf. Coat. Technol. 318, 129-141 (2017). https://doi.org/10.1016/j.surfcoat.2016. 09.012

69. W. Li, C. Cao, G. Wang, F. Wang, Y. Xu, and X. Yang, "'Cold spray +' as a new hybrid additive manufacturing technology: a literature review," Science and Technology of Welding and Joining, vol. 24, no. 5. Taylor and Francis Ltd., pp. 420-445, Jul. 04, 2019. https://doi.org/10.1080/13621718.2019.1603851.

70. A. M. Vardelle and N. J. Themelis, "Life cycle assessment-a comparison of various thermal spray processes and electroplating reliable model of DC plasma spray torch View project energy recovery from solid wastes View project," 2009, https://doi.org/ 10.13140/RG.2.1.1059.0480.

71. E. van Westing, V. Savran, and J. Hofman, "Materials innovation institute M2i Recycling of metals from coatings A desk study," 2013.

72. H. Kassner, R. Siegert, D. Hathiramani, R. Vassen, D. Stoever, Application of suspension plasma spraying (SPS) for manufacture of ceramic coatings. J Therm Spray Technol 17(1), 115-123 (2008). https://doi.org/10.1007/s11666-007-9144-2

73. A. Moign, A. Vardelle, N.J. Themelis, J.G. Legoux, Life cycle assessment of using powder and liquid precursors in plasma spraying: the case of yttria-stabilized zirconia. Surf. Coat. Technol. 205(2), 668-673 (2010). https://doi.org/10.1016/j.surfcoat.2010. 07.015 